\title{
Comparative Finite Element Analysis Of Metallic And Non Metallic Spur Gear
}

\author{
${ }^{1}$ Mahebub Vohra, ${ }^{2}$ Prof. Kevin Vyas \\ ${ }^{1}$ M.E. (CAD/CAM), Noble Group Of Institution, Junagadh (Gujarat), India. \\ ${ }^{2}$ Assistant professor, Noble Group Of Institution, Junagadh (Gujarat), India
}

\begin{abstract}
Gears are the very useful components in mechanical power transmission system and industrial rotating machinery. A spur gear generally subjected to two types of stresses like bending stresses and contact stresses which are causes teeth failure during meshing with another tooth. Gears are generally made from metallic materials but recently advanced polymers were developed which have sufficient strength and properties similar to the metallic materials so they can easily replace the metallic gears if some care will be taken. Nylon, polycarbonate, acetlas and delrin are the structure polymer materials used in printing and robotics mechanism with good functionality but polymers gears are not used in heavy loading type application. Especially polymer gear gives extra benefits compared to metallic gears like less noise-vibration, low requirement of maintenance-lubrication, low cost and easy manufacturing. This paper presents the design optimization methodology step by step using a static finite element method.
\end{abstract}

Keywords: Metallic and non metallic material, bending stress, static finite element analysis, facewidth, module, composite material.

\section{Introduction}

Gears are critical components of power transmission system and their size vary from small wrist watch gears to big rotating machinery gears. Gears are very useful due to its beneficialcharacteristics like constant velocity ratio and simple attachment for increase or decrease in speed of shaft so it is widely used in most of power transmission system.

According to position of shaft axis, gears classified as:

a) Parallel shaft axis

- Spur gear

- Helical gear

- Rack and pinion

b) Intersecting shaft axis

- Bevel gear

c) Non parallel non intersecting shaft axis

- Worm gears

- Spiral gears

- Hypoid gears

Gears are made from following types of materials as per application.

a) Metallic materials

- Malleable CI

b) Forged steel

i. Carbon steel

ii. Carbon chromium steel

iii. Carbon manganese

iv. Nickel chromium steel

c) Surface hardened steel

d) Case hardened steel

e) Nonmetallic and composite 


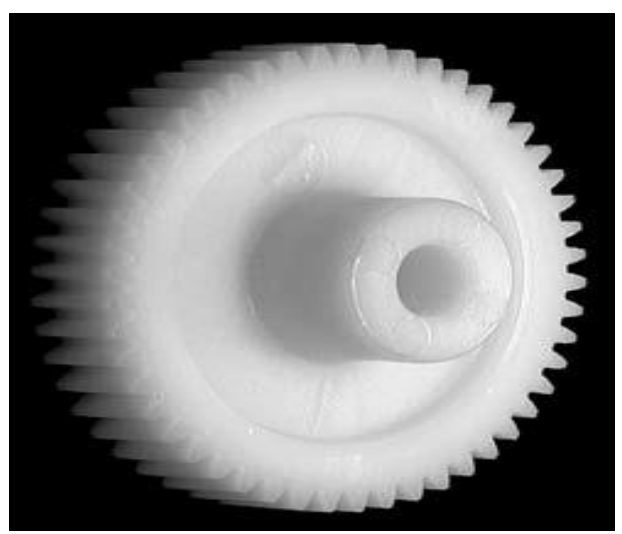

Fig 1 Polymer gear

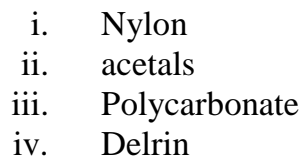

\section{Literature Studied}

The literatures mainly focus on replacement of metallic gears with polymers gears of light or medium power transmission system.

(1) V.Siva Prasad, Syed AltafHussain, V.Pandurangadu, K. PalaniKumar - In this paper, Design and analysis of spur gear and proposed to subtitle the metallic gears of sugar crane juice machine with Polymer gears to reduce the weight and noise. The main purpose of this paper to analyze the different polymer gears namely nylon, polycarbonate and their viability checked with counterpart metallic gear like as cast iron.By using the FEA methodology, they concluded that composite gears, if well designed and analyzed, it will give the useful properties like as low cost, noise, weight vibration and perform its operation similar to the metallic gears.

\section{(2) Dr.VanMelick}

Tooth bending effects in plastic spur gears, In this study, analysis was done byusing finite element methodology for the influence of the stiffness and the bending of plastic gear teeth due to increase in the contact path length in a considerable change in load sharing.In the preliminary and prolonged contact, the involute tooth flanks do not mesh properly, but the tooth tips make a reciprocating movement on the root of the other root.

Robert F. Handschuh, Gary D. Roberts, and Ryan R. Sinnamon

Comparative FEA and experimental analysis was carried out in this study.Composite material was used as web of the gear between the gear teeth and metallic hub for the mounting to applying torque to the shaft, the web portion bonded at inner and outer hexagonal form. This hybrid or composite gears are tested against an all steel gear. The hybrid gears operated successfully over 300 million cycles at $100 \mathrm{rpm}$ and found that composite gears are $20 \%$ lighter than all steel gears.Vibration test also done on the composite gears and compared it with steel.

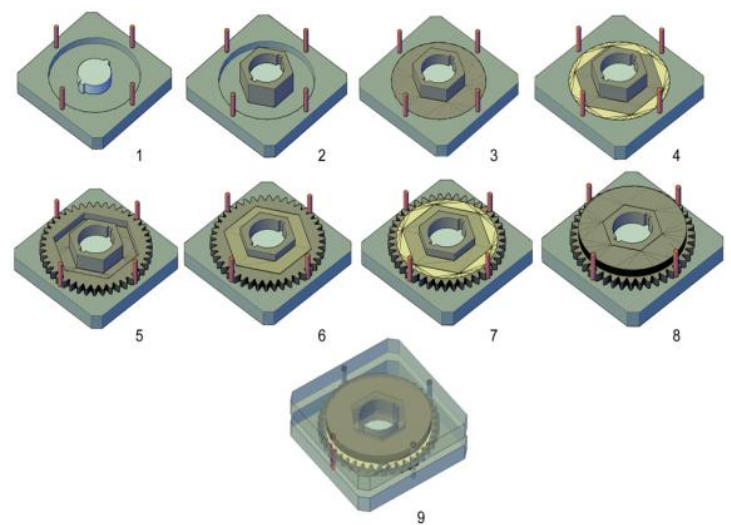

Fig. 2 Hybrid Gear 
gears, results show that composite gears are produce less vibration than steel gears.

(4) S. Senthilvelan and R. Gnanamoorthy,

Conduction monitoring conducted on the injection molded gears made of polymers, nylon and $20 \%$ glass filled nylon.By using Power absorption test ring, vibration and noise analysis for condition monitoring and found the possibility of early detection of gears tooth failures in case hardened spur gear. Also found that gear tooth surface temperature is increases and produce vibration at specific speed of rotation of the gears.

(5) Raymond M. Paquet, November/Decemeber1989

Systematic methodology was carried for complex design process to develop injection molded plastic spur gear and helical gears with the help of computer system. The systematic design process provided the design parameters for load carrying capacity, adequate contact, balance tooth thickness and proper clearance value for gears so no any bending effect will occur at extreme operating conditions.

(6) Laurentia ANDREI1, Gabriel ANDREI1, Douglas WALTON, 2006

This paper focus on the geometry of the tooth flank optimization. To determine the optimum value, gear tooth geometry changed and prepare gear solid model in computer software. Further this solid model imported in in analysis software to check the effect of loading on gear tooth by using a static finite element analysis. Here nonstandard plastic gear also discussed to optimize the gear.

(7) K Biernacki* and J Stryczek, December 2009

The plastic gear used in getro pump has been analyzed by using FEA. Solid model of gear set developed and checked strength analysis of model by finite element analysis. According to this study, there are two parts in the mesh, one is active parts where intertooth forces are induced between the teeth of internal and external gear, second one is passive part where intertooth forces do not occurred. The study concluded that gear deformation can be reduced in two ways first, by applying a higher strength plastic and second by modifying the cycloid gear set design.

(8) Gun-Hee Kim, Jeong-Won Lee,and Tae-Il Seo, 2013.

Durable characteristics analysis of worm wheel with glass reinforcement polymide performed in this paper. Both analytical and experimental methods were carried out for prediction of characteristic of plastic worm wheel. Computer aided engineering analysis were executed with the polymide resin reinforcement glass fiber. According to the result of this study, worm wheel of $50 \%$ glass fiber reinforcement content was advantageous in terms of deformation, which has a great effort on the operation of worm wheel. When glass fiber reinforcement content increases, strength and hardness potentially improve but damage may result from shock due to fluctuating external forces as the brittleness also increase. It also concluded that distribution of glass fiber reinforcement is not even, the strength and hardness of the worm wheel tooth profile might change which changes the properties of gear tooth.

(9) Mrs.Shinde S.P., Mr. Nikam A.A., Mr. Mulla T.S,

Gear tooth generally subjected to two types of cyclic stresses, bending stresses inducing bending fatigue and contact stresses causing contact fatigue. This type of failure analysis was performed and trying to design spur gear tooth profile to resist bending failure so for this finite element model and studied method was performed to calculate the bending stresses. Two results analytical and computer software-ANSYS were compared for the comparative analysis of different tooth profile.

Dr. Stefan Beermann,

This journal paper provides some guidelines to how evaluate the plastic gears and how to use design data for design and analysis of gear, also gives useful information about the measurement of material properties to make suitable for desire applications.

(11) VineetPandey, - failure analysis of gear materiall presents the various types of failure produced in gear during the meshing of two teeth. It suggests that stress related failure due to stress concentration in gear tooth profile. Detail metallurgical analysis also conducted on the gear model and compares it with to the new one gear in service condition. The study focus on the properties and limitation of industrial gear such as automobile and machinery to reduce the possibility of the gear. the thesis also describes the complete experimental work on the gear to determine the hardness of gear material at specific condition, varying hardness properties due to the different heat treatment process. The thesis conclude that failure is produced in gear because gar might be used at higher working pressure than pressure given by manufacture specification and stress produces in gear also 
higher than safe or design limit. In general, most of the failure produced in gear due to the high stress, low cycle fatigue failure, abrasion wear and plastic deformation.

(12) Zeping Wei, - Istresses and deformation in involute spur gears by finite element method. investigates the characteristics of an involute gear system including contact stresses, bending stresses, and the transmission errors of gears in meshing condition. When two gears are mesh for transmitting power from one shaft to another shaft. During this meshing gears produce noise and vibration and it is due to effect of transmission error. The estimation of transmission error in agear system, the characteristics of involute spur gears were analyzed by using the finite element methodology.

(13) Brenton L Ewing, - \Analysis of a Hybrid (composite-metal) spur gear subjected to stall torque using the finite element method. presents the hybrid spur finite element analysis. Hybrid material is an assembly of different parts of composite and metallic material for the purpose of a reduction of weight of a spur gear. All metallic parts analyzed by using a static finite element method and compare the result with a convention stress formula. He also investigates about the stress analysis of a spur gear with holes in a gear surface for the reduction of a weight. This study concludes that hybrid material is $20 \%$ lighter in weight compared to the conventional metallic spur gear.

\section{Gear System(Lathe Machine Headstock Gear Box)}

All material are not providing similar properties during working condition due to their different structure and bonding nature. Materials are to be required to check under loading conditions to find their beneficial properties and remove unnecessary properties during the selection of material. When gears are in a loading condition, mainly two types of failure are produced in gear material like as bending failure due to low bending strength of material and pitting or contact failure due to lower strength of contact area of gear teeth.

\section{Objectives Of The Work}

- Check comparative effect of produced stress in conventional metallic material of spur gears using a static finite element method.

- Check the non-metallic material using static finite element analysis.

- Check the stress analysis of gear parameter like as face width and module under loading condition.

- Check the possibility to replace metallic gear by other material like as polymer, composite or hybrid material for spur gear.

Following are the some specification about the lathe machine headstock gear which is used during entire project work.

Table 1 Lathe Machine Specification

\begin{tabular}{|c|c|}
\hline Manufacture Name & $\begin{array}{c}\text { Natraj Brand (most } \\
\text { precision) }\end{array}$ \\
\hline Electric motor & $2 \mathrm{HP}, 3 \mathrm{PH}, 1440 \mathrm{rpm}$ \\
\hline Gear type & Parallel spur gear \\
\hline Pressure angle & $20^{\circ}$ \\
\hline Module & 2 \\
\hline
\end{tabular}




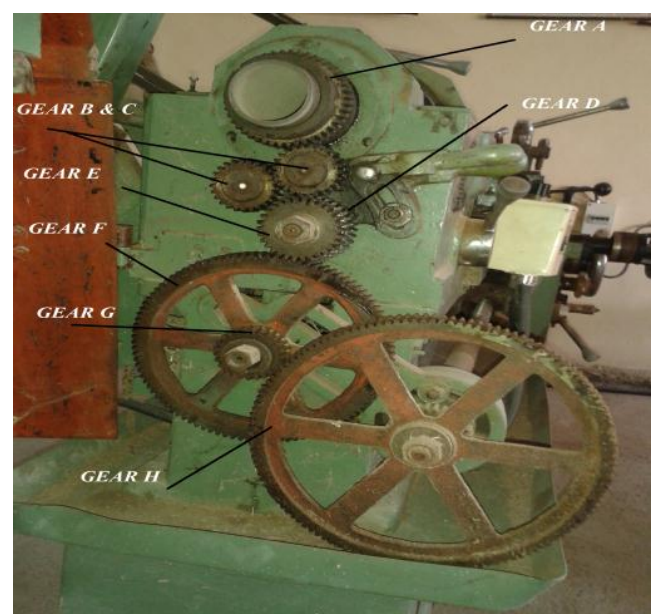

Fig. 3 Lathe machine headstock gear box

Table 2 Gear Parameter

\begin{tabular}{|c|c|c|}
\hline GEAR NAME & P.C.D (mm) & $\begin{array}{c}\text { NUMBER OF } \\
\text { TEETH }\end{array}$ \\
\hline A & 88 & 44 \\
\hline B & 50 & 25 \\
\hline C & 50 & 25 \\
\hline D & 66 & 33 \\
\hline E & 60 & 30 \\
\hline F & 200 & 100 \\
\hline G & 50 & 25 \\
\hline H & 254 & 127 \\
\hline
\end{tabular}

Table 3 Gear Calculation Data

\begin{tabular}{|c|c|c|c|c|}
\hline $\begin{array}{c}\text { Gear } \\
\text { Name }\end{array}$ & $\begin{array}{c}\text { Tangential } \\
\text { force } \\
(\mathbf{N})\end{array}$ & $\begin{array}{c}\text { Pitch } \\
\text { line } \\
\text { velocity } \\
(\mathbf{m} / \mathbf{s})\end{array}$ & $\begin{array}{c}\text { Bending } \\
\text { stress } \\
\boldsymbol{\sigma} \text { (LEwI) } \\
(\mathbf{M p a})\end{array}$ & $\begin{array}{c}\text { Bending } \\
\text { stress } \\
(\mathbf{M p a})\end{array}$ \\
\hline $\mathbf{A}$ & 224.86 & 6.63 & 13.70 & 16.93 \\
\hline $\mathbf{B , C , G}$ & 395.77 & 3.76 & 28.59 & 29.80 \\
\hline $\mathbf{D}$ & 299.82 & 4.97 & 17.23 & 22.20 \\
\hline $\mathbf{E}$ & 329.80 & 4.52 & 22.96 & 24.42 \\
\hline $\mathbf{F}$ & 98.94 & 15.07 & 5.53 & 7.32 \\
\hline $\mathbf{H}$ & 77.90 & 19.151 & 4.23 & 5.64 \\
\hline
\end{tabular}

Comparision between AGMA and Lewis Stress

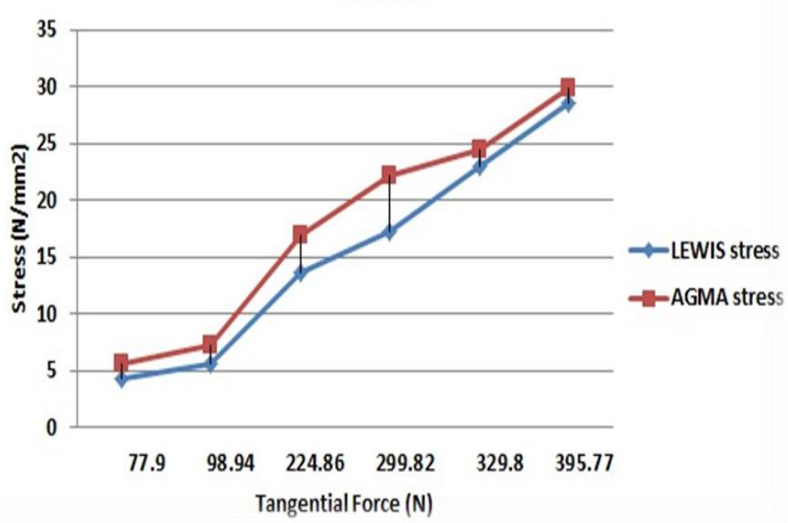

Graph 1 Comparison of AGMA and LEWIS 


\section{Solid Modeling And Material}

Solid modeling is a representation of a real physical object without losing any properties of the real physical object would have for the design and analysis purpose. A solid model has a different properties like as density, mass, inertia and volume so it is very easy to understand about model of the physical object.

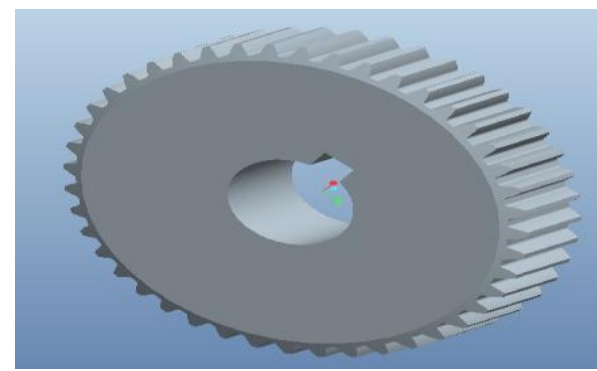

Fig. 4 Gear Model

CAST IRON (METALLIC MATERIAL): Cast iron is a common material for the manufacturing of the gear. Cast iron is widely used due to its beneficial properties such as goof wearing properties, low noise during power transmission, machinability and simplicity in producing complicated shape-smaller to bigger size by different casting method.

Table 4 CI properties

\begin{tabular}{|c|c|}
\hline $\begin{array}{c}\text { Tensile Ultimate } \\
\text { stress }\end{array}$ & $320-350 \mathrm{~N} / \mathrm{mm}^{2}$ \\
\hline $\begin{array}{c}\text { Modulus of } \\
\text { elasticity }\end{array}$ & $1.65 * 10^{5} \mathrm{~N} / \mathrm{mm}^{2}$ \\
\hline Density & $7.2 * 10^{-6} \mathrm{Kg} / \mathrm{mm}^{3}$ \\
\hline Poisson ratio & 0.25 \\
\hline
\end{tabular}

NYLON (NON-METALLIC MATERIAL): Nylon is a generic designation for a family of synthetic polymers known generically as aliphatic polyamides which was first produced on February 28, 1935, in Wallace Carothers at DuPont's research facility at the DuPont Experimental Station. Engineering-grade nylon is processed by extrusion, casting, and injection moulding.

Table 5 Nylon Properties

\begin{tabular}{|c|c|}
\hline Tensile Ultimate stress & $65 \mathrm{~N} / \mathrm{mm}^{2}$ \\
\hline Modulus of elasticity & $2.20 \mathrm{Gpa}$ \\
\hline Density & $1.12 \mathrm{~g} / \mathrm{cc}$ \\
\hline Poisson ratio & 0.37 \\
\hline
\end{tabular}

\section{Static Finite Element Method}

Finite element analysis is an important method to check the gear material under a loading condition. In this section, the Bending stress of a gear material is checked by a FEM software package ANSYS. For this purpose, 3D model is prepared in Pro-engineer modeling software with a sufficient geometry properties and then it is imported in a ANSYS as n Initial Graphic Exchange System (IGES) file. Automatic mesh generation tool is used in ANSYS to divide the geometry in number of element for a desired accuracy of result. In general, there are three phases in any finite element analysis task:

1. Pre-processing - defining the finite element model and environmental factors be applied to it.

2. Analysis solve - solution of finite element model

3. Post-processing of results using visualization tools

\section{Fem Stress Analysis}

Bending stress of spur gear teeth is generally calculated by analytically and finite element method. In this chapter, static finite element method is applied on the spur gear teeth for a different material of a spur gear. Analytical bending stress is calculated by two formula Lewis formula and AGMA formula. Analytical result is compared with the finite element method result for validation. von mises stress are equal to the tension stress and generally it is main cause of crack in the gear teeth if the load applied load is greater than strength of the gear teeth so gear teeth is crack from tensile force. 


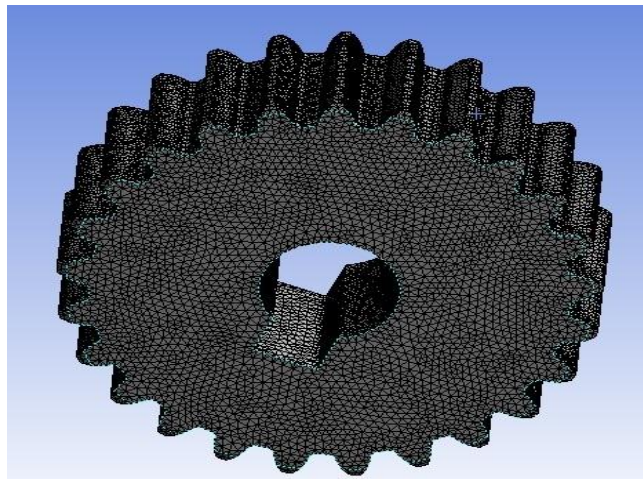

Fig. 5 Meshing of gear

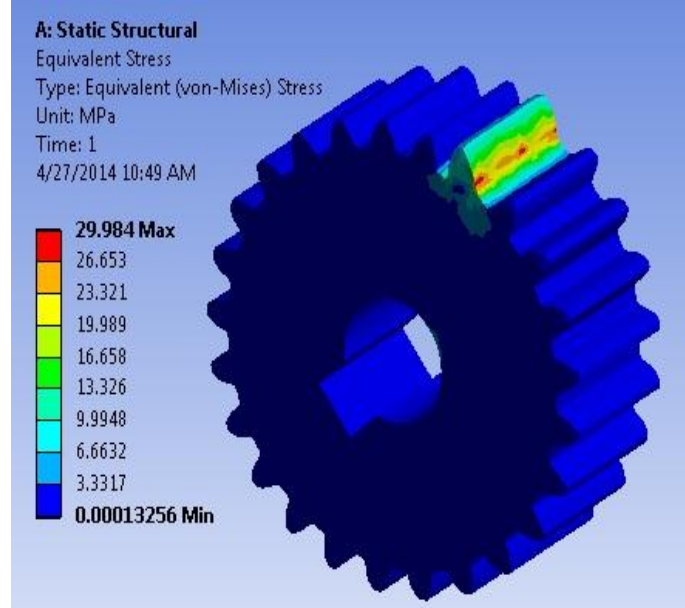

Fig. Gear B von mises stress distribution in Cast Iron

Graph 2 \& 3 Comparison of AGMA and CI-NYLON stress

Effect of Tangential force on CAST IRON

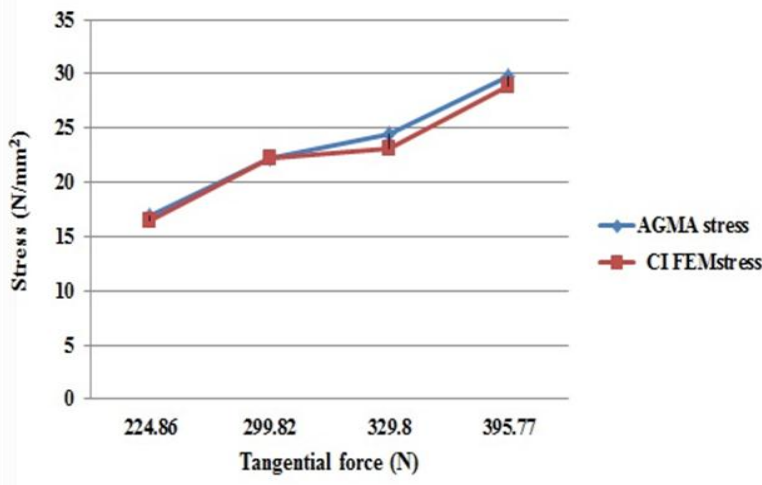


Effect of Tangential force on NYLON

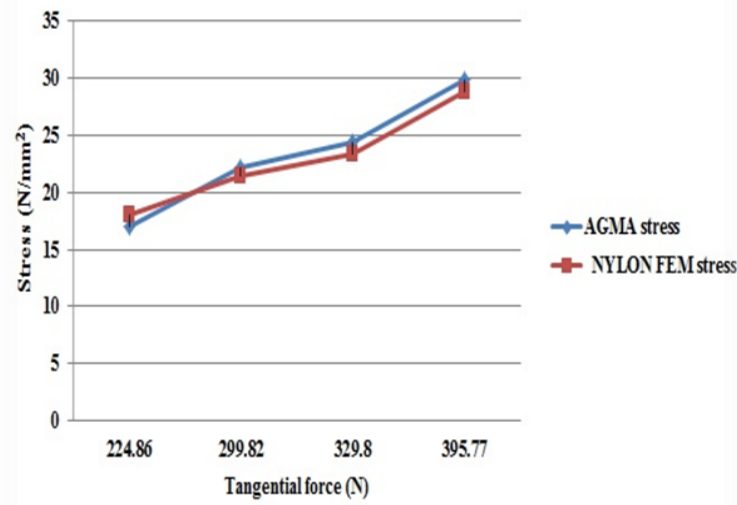

Table 6 Comparison of AGMA and FEM stress

\section{Effects Of Parameters On Spur Gear}

As per shown in table and comparative stress graph, the maximum stresses are increase with decrease in the value of the face width-module and decrease bending stress with increase in the face width-module of gear.

\begin{tabular}{|c|c|c|c|c|}
\hline $\begin{array}{l}\text { Gear } \\
\text { specifi } \\
\text { cation }\end{array}$ & $\begin{array}{c}\text { Face } \\
\text { width of } \\
\text { gear } \\
(\mathrm{mm})\end{array}$ & $\begin{array}{c}\sigma \\
(\mathbf{A G M A} \\
)^{)} \\
(\mathbf{M p a} \\
\text { ) }\end{array}$ & 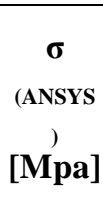 & $\begin{array}{c}\text { Differen } \\
\text { ces [\%] } \\
\pm\end{array}$ \\
\hline \multirow{10}{*}{$\begin{array}{c}\text { Module } \\
-2 \mathrm{~mm} \\
\text { No. of } \\
\text { Teeth- } \\
25\end{array}$} & 8 & 74.50 & 77.05 & 3.30 \\
\hline & 10 & 59.60 & 62.15 & 4.1 \\
\hline & 12 & 49.66 & 49 & 1.3 \\
\hline & 14 & 42.57 & 42.86 & 0.6 \\
\hline & 16 & 37.25 & 36.54 & 1.9 \\
\hline & 18 & 33.11 & 32.57 & 1.6 \\
\hline & 20 & 29.80 & 29.98 & 0.6 \\
\hline & 22 & 27.09 & 28.12 & 3.66 \\
\hline & 26 & 22.92 & 22.92 & 0 \\
\hline & 30 & 19.86 & 19.96 & 0.5 \\
\hline
\end{tabular}

\begin{tabular}{|l|c|l|c|c|c|}
\hline $\begin{array}{l}\text { GEAR } \\
\text { NAME }\end{array}$ & $\begin{array}{c}\text { MODUL } \\
\text { E }\end{array}$ & $\begin{array}{l}\text { P.C. } \\
\text { D }\end{array}$ & $\begin{array}{c}\text { AGMA } \\
\text { STRES } \\
\text { S[Mpa] }\end{array}$ & $\begin{array}{c}\boldsymbol{\sigma} \\
\text { (ANSYs) } \\
\text { [Mpa] }\end{array}$ & $\begin{array}{c}\text { Diff. } \\
{[\%]} \\
\mathbf{\pm}\end{array}$ \\
\hline & 1 & 25 & 59.60 & $\begin{array}{c}67.37 \\
8\end{array}$ & $\begin{array}{c}11.5 \\
4\end{array}$ \\
\cline { 2 - 6 } & 2 & 50 & 29.80 & 28.82 & 3.40 \\
\cline { 2 - 6 } & 3 & 75 & 19.86 & 19.43 & 2.21 \\
\cline { 2 - 6 } $\begin{array}{l}\text { Gear : B } \\
\begin{array}{l}\text { No. of } \\
\text { Teeth: } \\
25\end{array}\end{array}$ & 4 & 100 & 14.90 & 13.9 & $\begin{array}{c}14.2 \\
4\end{array}$ \\
\cline { 2 - 6 } & 6 & 150 & 9.93 & 10.32 & 3.77 \\
\cline { 2 - 6 } & 10 & 250 & 5.96 & 6.86 & $\begin{array}{c}13.1 \\
1\end{array}$ \\
\cline { 2 - 6 } & 12 & 300 & 4.96 & 5.81 & $\begin{array}{c}14.6 \\
9\end{array}$ \\
\hline
\end{tabular}




\begin{tabular}{|c|c|c|c|c|}
\hline Gear Name & $\begin{array}{c}\text { Gear } \\
\text { Material }\end{array}$ & $\begin{array}{c}\sigma_{(\text {AGMA })} \\
{[\text { Mpa] }}\end{array}$ & $\begin{array}{c}\sigma_{\text {(ANSYS ) }} \\
{[\text { Mpa] }}\end{array}$ & $\begin{array}{c}\text { Differen } \\
\text { ce \% } \\
\pm\end{array}$ \\
\hline \multirow{2}{*}{$\begin{array}{c}\text { Number of } \\
\text { teeth - } 44 \\
\text { Pitch circle } \\
\text { dia. }-88\end{array}$} & Cast iron & \multirow[b]{2}{*}{16.93} & 16.514 & 2.45 \\
\hline & Nylon & & 18.105 & 6.73 \\
\hline \multirow{2}{*}{$\begin{array}{l}\text { Number of } \\
\text { teeth }-25 \\
\text { Pitch circle } \\
\text { dia. }-50 \mathrm{~mm}\end{array}$} & Cast iron & \multirow[b]{2}{*}{29.80} & 29.984 & 0.61 \\
\hline & Nylon & & 28.82 & 3.26 \\
\hline \multirow{2}{*}{$\begin{array}{l}\text { Number of } \\
\text { teeth - } 33 \\
\text { Pitch circle } \\
\text { dia. }-66 \mathrm{~mm}\end{array}$} & Cast iron & \multirow[b]{2}{*}{22.20} & 22.206 & 0.02 \\
\hline & Nylon & & 21.385 & 3.67 \\
\hline \multirow{2}{*}{$\begin{array}{l}\text { Number of } \\
\text { teeth - } 30 \\
\text { Pitch circle } \\
\text { dia. }-60 \mathrm{~mm}\end{array}$} & Cast iron & \multirow{2}{*}{24.42} & 23.076 & 5.50 \\
\hline & Nylon & & 23.41 & 4.13 \\
\hline
\end{tabular}
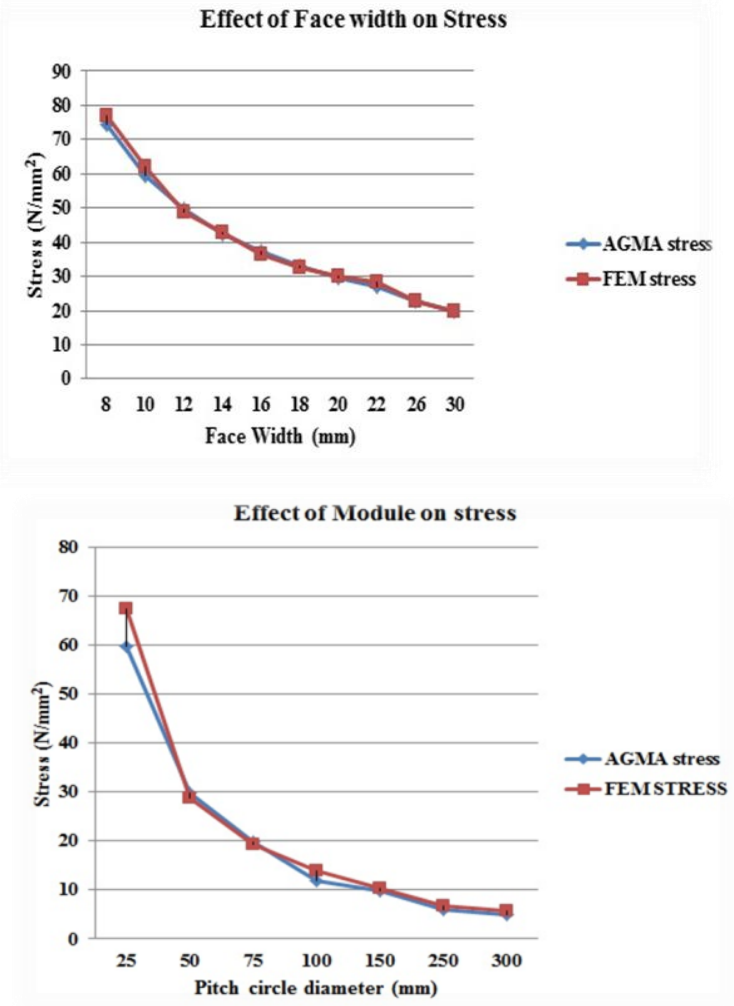

Graph 4 \& 5 Effect of facewidth and module on stress

Different material study provides the information for the bending stress of each material. Simulation result has good agreement with the theoretical result, which implies that deformable body is correct. This study provides a sound foundation for future studies on bending stresses. The study is applied in to finite element method software ANSYS. It was found that numerically obtained values of stress distributions were in good agreement with the theoretical results.

Nonmetallic material spur gear provides extra benefits like as less cost, self-lubricating, low noise, low vibration and easy manufacturing if it is used in limit of yield strength. It can be used in place of metallic gear in limit of yield strength of nonmetallic material. 
The bending stress is increase when decrease in the face width and module while increasing the face width and module, bending stress is decreased.

\section{References:}

[1] V. Siva Prasad1, Syed AltafHussain, V.Pandurangadu, K.PalaniKumar, "Modeling and Analysis of Spur Gear for Sugarcane Juice Machine under Static Load Condition by Using FEA".Vol.2, Issue.4, July-Aug 2012 pp-2862-2866

[2] K Biernacki* and J Stryczek "Analysis of stress and deformation in plasticgears used in gerotor pumps.21 December 2009

[3] Dr. van Melick, "Tooth-bending effects in plastic gears. September/octomber 2007.

[4] Raymond M. Paquet, Plastic gearing technology,inc. “ systematic approach to designing plastic spur and helical geras. November/Decemeber1989, gear technology-the journal of gear manufacturing.

[5] Gun-Hee Kim, Jeong-Won Lee,and Tae-Il Seo, "Durability Characteristics Analysis of Plastic Worm Wheel withGlass Fiber Reinforced Polyamide"Materials 2013.

[6] Laurentia ANDREI1, Gabriel ANDREI, Douglas WALTON, “Optimisationofthe toothflank geometryfor nonstandard spur gear. FASCICLE VIII, 2006

[7] Robert F. Handschuh, Gary D. Roberts, and Ryan R. Sinnamon “Application ofComposites to Dynamic Mechanical Components". NASA,NASA/TM-2012

[8] Mrs.Shinde S.P., Mr. Nikam A.A., Mr. Mulla T.S. "Static Analysis of Spur Gear Using Finite Element Analysis".

[9] Dr. Stefan Beermann, "Estimation of lifetime for plastic gears".

[10] S. Senthilvelan and R. Gnanamoorthy, "Condition Monitoring Of Nylon And Glass Filled Nylon Gears"

[11] Vineet Pandey, P.G Thesis, Failure analysis of Gear material, school of physics and material science, Thapar University, July 2009.

[12] Zeping Wei, Stress and Deformation in Involute Spur gears by Finite Element Method, October 2004.

[13] Brenton L Ewing, P.G Thesis, Analysis of a Hybrid (composite-metal) spur gear subjected to stall torque using the finite element method, December 2013

[14] Gitin Maitra $\bullet$ Hand book of gear design. 2nd edition.

[15] Dr. P.C. Sharma, Dr. D.K. Aggarwal, -Machine designl,S.K. Kataria \& Sons.

[16] George E. Dieter, Linda C. Schmidt, - Engineering designll,Mcgraw-Hill. 